\title{
MAJOR ELEMENT GEOCHEIMISTRY OF THE GRANITIC ROCKS
}

\author{
RISTO PIISPANEN
}

\begin{abstract}
PIISPANEN, RISTO 1977: Major element geochemistry of the granitic rocks. Bull. Geol. Soc. Finland 49 (2): $73-78$.

Chemical data on major components in 195 granitic rocks, mainly Finnish, were extracted from the geological literature, stored in a data processing system and treated statistically. This enabled the chemical characteristics of an average granitic rock with corresponding element distributions to be calculated; these data are reported here, with a discussion of their geological implications. The compositional limits within which a granitic rock should fall in most cases may also be deduced form the element distributions presented.

Among the individual components, silica and potassium show negative skewness, $\mathrm{Al}_{2} \mathrm{O}_{3}, \mathrm{Na} 2 \mathrm{O}$ and $\mathrm{H}_{2} \mathrm{O}^{+}$roughly normal distribution and ferric and ferrous iron, $\mathrm{CaO}$ and $\mathrm{MgO}$ show positive skewness, the rest of the oxides appearing with rapidly diminishing frequency towards higher concentrations. The negative skewness is indicative of the transitionality of the granites towards more basic rocks and reflects the difficulty encountered in defining a granite in a chemically-based classification.

A slight bimodality obtains for $\mathrm{Fe}_{2} \mathrm{O}_{3}, \mathrm{TiO}_{2}$ and $\mathrm{MgO}$, indicating the presence of the rapakivi granites in the sample population and implying their unrelatedness to other granitic rocks.
\end{abstract}

Risto Piispanen, Department of Geology, University of Oulu, Kasarmintie 15, SF-90100 Oulu 10, Finland.

\section{Introduction}

Although the petrogenetical aspects of the granite problem have been actively discussed in the geological literature for a long time, it is somewhat astonishing to note how difficult it is to find numerical data concerning the average chemical composition, ranges of variation and distributions of the individual components of these much-disputed rocks. A knowledge of the chemical characteristics would facilitate the delineation of the subject matter and also be useful for classificatory purposes, while componential frequency distributions could be useful in revealing the eventual homogeneity or heterogeneity of this rock class and its possible transitionality with other groups. An eventual bimodality in the distribution graphs would reflect a mixed, dichotomous nature in the rock population, while skewnesses should reflect the transitionality of the rock group with others. The relative frequency distribution patterns can also be assumed to show marked kurtosis if a rock class is petrographically welldefined, and the same can be expected if a 
rock class is an independent one showing no kinship with other rocks either by differentiation from a common source or by being a product of the same generative process (e.g. granitization or palingenesis). With the aid of distribution histograms it is also easy and instructive to compare a new analysis with the old data and thus distinguish its normality or abnormality.

For these purposes, and in order to evaluate the average chemical composition and other chemical characteristics of a granitic rock, a total of 195 chemical analyses of granitic rocks was assembled from the Finnish geological literature. All the analyses under the petrographical name granite as used by the criginal writers, and also the various types of rapakivi, were accepted. The material did not encompass rocks classified as granodiorites, quartz diorites, etc. All the figures reported in the original papers were accepted as such, without screening, no a priori compositional limits being set for the highest or lowest values to be accepted. Thus the highest and lowest values indicated in Table 1 are pure minimum and maximum values for the individual component encountered.

\section{The data sources}

The chemical analyses of the rocks now under discussion have all appeared earlier in the Finnish geological literature. The oldest data are derived from Lokka (1934 and 1950) who published two catalogues containing practically all the analyses performed and published in Finland up to 1950. As no similar attempt has subsequently been made, the two papers by Lokka remain the most important sources of data. The reference numbers of those analyses from Lokka's lists that have been incorporated in the data file for the present study are listed in the Appendix.

The data from the more recent analyses postdating Lokka's papers were collected by searching the most important sources of Finnish geological literature, notably the Geological Survey bulletins and the explanations accompanying the geological maps published by the Geological Survey of Finland. The Appendix also gives detailed source lists for the data obtained from these publications.

\section{Average composition and other chemical characteristics}

The computed arithmetic means for the various oxide percentages of the granitic rocks studied are given in Table 1 . Some earlier results are also given for comparison. The last two columns give the average reported by Sederholm (1925) and the figures of Simonen (1960) for an average of five Svecofennidic microcline granites from southwestern Finland. The figures reported by Sederholm represent an average of five different age and regional variety groups, this consequently being an »average of averages» (Sederholm 1925, Table II).

The mean value for silica given by Sederholm is markedly lower than that obtained here, while in the aluminas the relations are the reversed. The most important difference is, however, the difference in the figures for magnesia, that of Sederholm's being considerably higher than that calculated here.

Sederholm himself admitted that his figure for magnesia was too high $(1925$, p. 7$)$, and explained it as resulting from the calculation of an average for five different averages calculated earlier in the same paper. A glance at the averages (op.cit., Table 1), however, reveals that none of these alone showed such a high percentage of magnesia, and the high figure therefore remains unexplained.

The average values given by Simonen (op.cit) also differ from those calculated here, obviously due to the fact that the present work includes the rapakivi granites whereas 
Table 1. Arithmetic means, standard deviations and other statistical parameters of the 195 studied granitic rocks. For comparison, the averages given by Sederholm (1925) and Simonen (1960) are also given.

\begin{tabular}{|c|c|c|c|c|c|c|c|c|c|}
\hline & $\begin{array}{l}\text { Arith- } \\
\text { metic } \\
\text { mean }\end{array}$ & $\begin{array}{l}\text { Standard } \\
\text { deviation }\end{array}$ & $\begin{array}{c}\text { Standard } \\
\text { error }\end{array}$ & $\begin{array}{c}\text { Number } \\
\text { of } \\
\text { analyses }\end{array}$ & $\begin{array}{l}\text { Mini- } \\
\text { mum } \\
\text { value }\end{array}$ & $\begin{array}{l}\text { Maxi- } \\
\text { mum } \\
\text { value }\end{array}$ & $\begin{array}{l}\text { Range of } \\
\text { variation }\end{array}$ & $\begin{array}{l}\text { Seder- } \\
\text { holm }\end{array}$ & Simonen \\
\hline $\mathrm{SiO}_{2}$ & 71.18 & 3.74 & 0.27 & 195 & 61.06 & 78.97 & 17.91 & 69.42 & 73.55 \\
\hline $\mathrm{TiO}_{2}$ & 0.42 & 0.31 & 0.02 & 187 & 0.00 & 2.49 & 2.49 & 0.39 & 0.22 \\
\hline $\mathrm{Al}_{2} \mathrm{O}_{3}$ & 14.03 & 1.49 & 0.11 & 195 & 11.08 & 20.57 & 9.49 & 14.70 & 13.85 \\
\hline $\mathrm{Fe}_{2} \mathrm{O}_{3}$ & 0.94 & 0.76 & 0.05 & 194 & 0.00 & 6.00 & 6.00 & 1.08 & 0.82 \\
\hline $\mathrm{FeO}$ & 2.10 & 1.41 & 0.10 & 195 & 0.09 & 6.35 & 6.26 & 2.49 & 1.38 \\
\hline $\mathrm{MnO}$ & 0.05 & 0.05 & 0.00 & 186 & 0.00 & 0.52 & 0.52 & 0.03 & 0.03 \\
\hline $\mathrm{MgO}$ & 0.59 & 0.56 & 0.04 & 193 & 0.00 & 2.47 & 2.47 & 2.02 & 0.38 \\
\hline $\mathrm{CaO}$ & 1.87 & 1.15 & $0.1) 8$ & 195 & 0.10 & 5.38 & 5.28 & 1.44 & 1.36 \\
\hline $\mathrm{Na}_{2} \mathrm{O}$ & 3.35 & 0.85 & 0.06 & 195 & 1.76 & 5.96 & 4.20 & 3.24 & 2.93 \\
\hline $\mathrm{K}_{2} \mathrm{O}$ & 4.58 & 1.62 & 0.12 & 195 & 0.42 & 9.05 & 8.63 & 4.46 & 5.18 \\
\hline $\mathrm{P}_{2} \mathrm{O}_{5}$ & 0.15 & 0.16 & 0.01 & 180 & 0.00 & 1.12 & 1.12 & 0.07 & 0.04 \\
\hline $\mathrm{H}_{2} \mathrm{O}^{+}$ & 0.59 & 0.35 & 0.03 & 173 & 0.04 & 2.32 & 2.28 & 0.66 & 0.38 \\
\hline $\mathrm{H}_{2} \mathrm{O}-$ & 0.12 & 0.09 & 0.01 & 169 & 0.00 & 0.56 & 0.56 & & 0.12 \\
\hline
\end{tabular}

Simonen's material consisted of uniform microcline granites only. This explains the differences in sodium and potassium. All the values reported by Simonen, however, fall within the limits given later in the present paper for a »typical» granite (Table 2), and are therefore not markedly different from the present ones.

\section{Frequency distributions}

The relative frequency distribution patterns for the various components are depicted in Fig. 1. A marked negative skewness obtains for silica and potassium, ferric and ferrous iron, $\mathrm{MgO}$ and $\mathrm{CaO}$ are positively skewed, while alumina, $\mathrm{Na}_{2} \mathrm{O}$ and $\mathrm{H}_{2} \mathrm{O}^{+}$show roughly normal distribution. The rest of the oxides tend to feature rapidly diminishing frequencies towards the higher concentrations.

The geological implication of the negative skewness of silica and potassium is a gradual transitionality of the granitic rocks towards the more basic rocks. If the rock group were of an independent and non-transitional character a symmetrical distribution around a central value could be expected. On the other hand, the abrupt drop in relative frequencies at about $76 \% \mathrm{SiO}_{2}$ reflects the nontransitionality of granites towards the even more acidic rocks, excluding only the rare aplitic and pegmatitic varieties which are rich in quartz.

The presence of the rapakivi types in the sample population is, perhaps, reflected in the slight bimodalities of $\mathrm{TiO}_{2}, \mathrm{FeO}$ and $\mathrm{MgO}$.

The chemical characteristics of a »typical» granite can also be estimated on the basis of the frequency distribution diagrams. Thus the percentages for the various componential oxides should in most cases have a value within the boundaries given in Table 2 .

Table 2. Compositional limits for a »typical» granitic rock as deduced from the frequency distributions (Fig. 1).

\begin{tabular}{|lr|ll|}
\hline $\mathrm{SiO}_{2}$ & $70.00-76.00$ & $\mathrm{CaO}$ & $0.60-2.40$ \\
$\mathrm{TiO}_{2}$ & $0.00-0.60$ & $\mathrm{Na}_{2} \mathrm{O}$ & $2.40-3.60$ \\
$\mathrm{Al}_{2} \mathrm{O}_{3}$ & $12.00-15.00$ & $\mathrm{~K}_{2} \mathrm{O}$ & $4.00-6.00$ \\
$\mathrm{Fe}_{2} \mathrm{O}_{3}$ & $0.00-1.20$ & $\mathrm{P}_{2} \mathrm{O}_{5}$ & $0.00-0.40$ \\
$\mathrm{FeO}$ & $0.70-2.10$ & $\mathrm{H}_{2} \mathrm{O}^{+}$ & $0.30-0.90$ \\
$\mathrm{MnO}$ & $0.00-0.12$ & $\mathrm{H}_{2} \mathrm{O}-$ & $0.00-0.20$ \\
$\mathrm{MgO}$ & $0.00-0.60$ & & \\
\hline
\end{tabular}



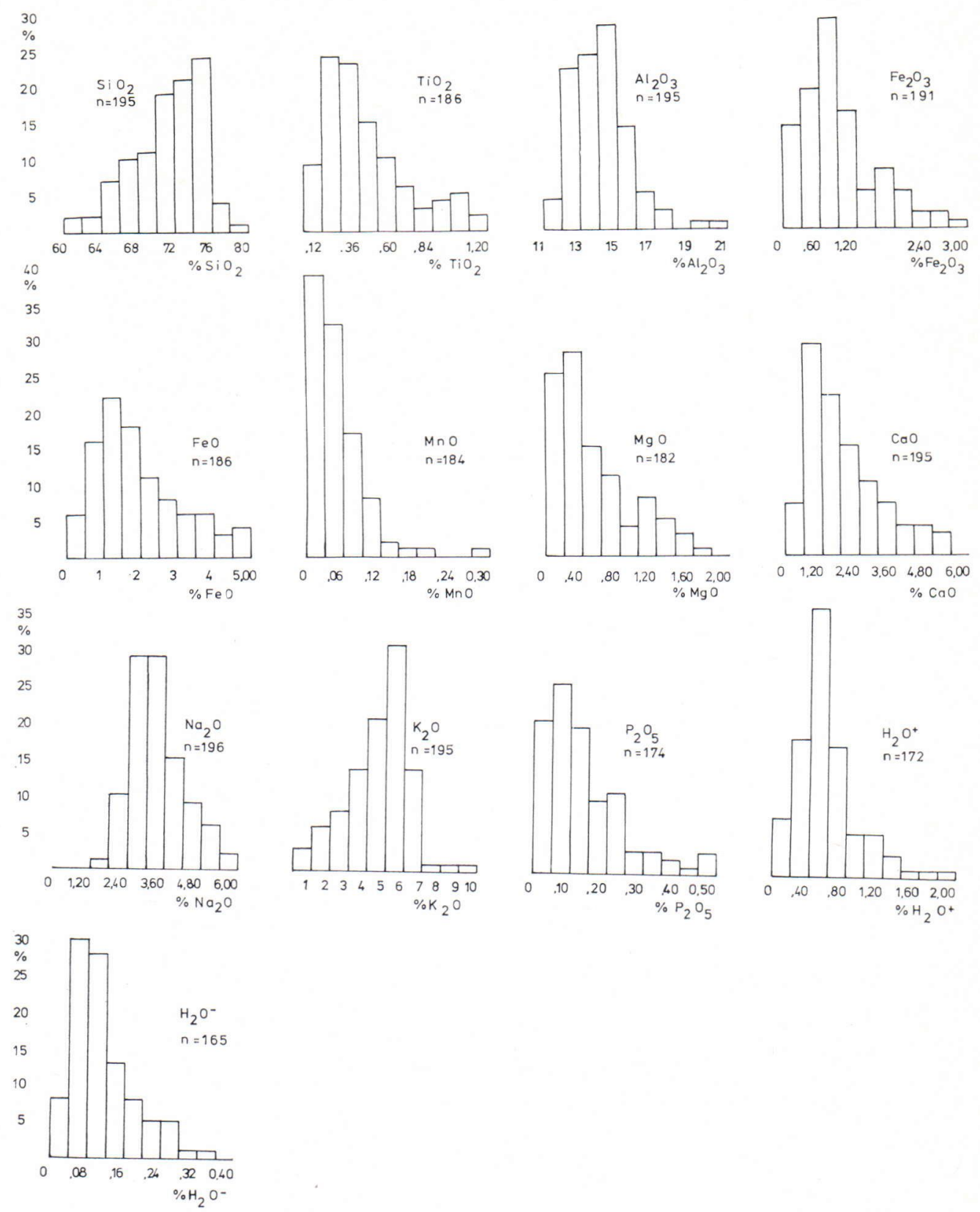

Fig. 1. Frequency distributions of the major oxide components in the studied granitic rocks.

Acknowledgements - The computations and frequency distribution study were performed using the University of Oulu time-sharing Honeywell 1402 computer system through a remote terminal at the Department of Geology. The help of Mr. Tuomo Alapieti in the actual run of the computer in acknowledged. Mrs. Toini Mattila helped in accumulating the data, Mrs. Raili Iunnila typed the manuscript and Mrs. Ellen Komulainen drew the histogram and, last but not least, Professor Malcolm Hicks corrected the English of the manuscript. To all of these people the author is greatly indebted. 


\section{References}

Lokka, L. (1934) Neuere chemische Analysen von finnischen Gesteinen. Bull. Comm. Géol. Finlande 105.

Lokka, L. (1950) Chemical analyses of Finnish rocks. Bull. Comm. Géol. Finlande 151.

Sederholm, J. J. (1925) The average composition of the Earth's crust in Finland. Bull. Comm. Géol. Finlande 70.

Simonen, A. (1960) Plutonic rocks of the Svecofennides in Finland. Bull. Comm. Géol. Finlande 189.

\section{Appendix}

\section{List of data sources}

The data for the present work are derived from earlier Finnish geological publications. A detailed list of sources is given here in order to facilitate future reference.

Table 3. List of the issues of the Bulletin of the Geological Survey of Finland (formerly Bulletin de la Commission Géologique de Finlande) from which analysis data were incorporated in the present data files. The issue numbers are listed with corresponding page numbers, numbers of analyses obtained and year of publication. The last row gives the issue number of the Bulletin of the Geological Society of Finland from which 9 analyses were also extracted.

\begin{tabular}{|c|c|c|c|}
\hline Issue no. & Page(s) & $\begin{array}{c}\text { Number of } \\
\text { analyses }\end{array}$ & $\begin{array}{c}\text { Year of } \\
\text { publication }\end{array}$ \\
\hline & & & \\
152 & 32 & 2 & 1951 \\
153 & 50 & 1 & 1951 \\
153 & 70 & 1 & 1951 \\
163 & $40-41$ & 2 & 1953 \\
172 & 77 & 3 & 1956 \\
172 & 88 & 2 & 1956 \\
204 & $116-119$ & 2 & 1962 \\
212 & $92-3$ & 2 & 1964 \\
212 & 58 & 1 & 1964 \\
219 & $12-19$ & 4 & 1965 \\
221 & $14-15$ & 3 & 1966 \\
238 & 9 & 2 & 1969 \\
243 & 30 & 1 & 1971 \\
246 & 8 & 7 & 1971 \\
43 & 30 & 9 & \\
\hline
\end{tabular}

The data sources can be classified into three main groups, listed separately in Tables 3-5. Firstly, a large proportion of the analysis figures were derived from issues of the Bulletin of the Geological Survey of Finland (formerly Bulletin de la Commission Géologique de Finlande). A list of these is given in Table 3 , with issue numbers, relevant page numbers and years of publication.

Another very fruitful source of data consisted of the explanations to the Geological Map of Finland published by the Geological Survey of Finland (Suomen geologinen kartta 1: 100100 , Geological Map of Finland 1: 100 000, Kallioperäkartan selitys, Explanation to the map of rocks). The individual map sheets utilized, with corresponding page numbers and years of publication are given in Table 4. The number of analyses taken from each issue is also given.

As previously mentioned, Lokka compiled two booklets presenting hundreds of wholerock chemical analyses of Finnish rock samples of all kinds (Lokka 1934 and 1950).

Table 4. List of the Explanations to the map of rocks (Suomen geologinen kartta 1:100 000 Kallioperäkartan selitys, Geological Map of Finland 1: 100000 , Explanation to the map of rocks) from which chemical data were abstracted for the present data files.

\begin{tabular}{|l|c|c|c|}
\hline Name of the sheet & Page(s) & $\begin{array}{c}\text { Number } \\
\text { of } \\
\text { analyses }\end{array}$ & $\begin{array}{c}\text { Year of } \\
\text { publi- } \\
\text { cation }\end{array}$ \\
\hline Ikaalinen & $72-3$ & 2 & 1952 \\
Korsnäs & 28 & 2 & 1960 \\
Lapinjärvi & 28 & 6 & 1963 \\
Lestijärvi-Reisjärvi & 26 & 6 & 1967 \\
Loimaa & 40 & 1 & 1953 \\
Pyhäjoki-Vihanti & 13 & 7 & 1965 \\
Raahe-Paavola & 35 & 1 & 1959 \\
Siuntio & $20-22$ & 3 & 1961 \\
Suomusjärvi & 38 & 1 & 1955 \\
Viljakkala-Teisko & 67 & 1 & 1952 \\
\end{tabular}


Those numbers from his lists which were files are given in Table 5. Lokka's original designated granite or rapakivi or the like and numbering is preserved.

which were incorporated in the present data

Table 5. List of analyses taken from Lokka'scollections (1934 and 1950), using the original numbering.

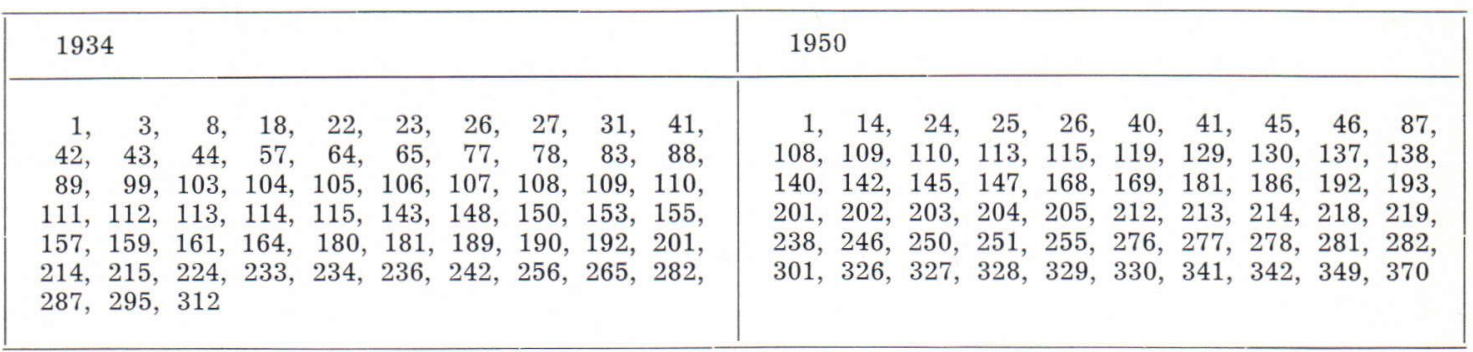

Manuscript received November 8, 1976. 